\title{
PENGARUH PENAMBAHAN TEPUNG DAUN JATI DALAM RANSUM TERHADAP PROFITABILITAS AYAM PETELUR
}

\author{
The Effect of Dietary Teak Leaves Powder Supplementation on Profitability of Laying Hens
}

\author{
Didik Nur Edi \\ Section of Animal Breeding and Forage for Animal Feed, Technical Implementation Unit of Animal \\ Breeding and Animal Health of Madura, East Java Provincial Livestock Service \\ Jl Raya Pamekasan-Sumenep Km. 08, Desa Grujungan, Kec. Larangan, Kab. Pamekasan, \\ Jawa Timur 69383 \\ E-mail: didiknuredi@yahoo.co.id
}

Submitted : February 24, $2020 \quad$ Accepted : November 29, 2020

\begin{abstract}
ABSTRAK
Penelitian ini dilakukan untuk mengevaluasi pengaruh penggunaan tepung daun jati sebagai alternatif pengganti antibiotik sintetis terhadap profitabilitas ayam petelur. Materi yang digunakan pada penelitian ini adalah 240 ekor ayam petelur strain Isa Brown berumur 30 minggu. Ayam petelur tersebut dikelompokkan secara acak ke dalam 6 perlakuan dengan 4 ulangan (masing-masing ulangan menggunakan 10 ekor ayam petelur). Perlakuan yang digunakan terdiri dari perlakuan kontrol: tanpa aditif pakan, AV: $0,05 \%$ antibiotik virginiamycin, dan penambahan tepung daun jati pada level $0,4 \%, 0,8 \%, 1,2 \%$, dan $1,6 \%$. Hasil penelitian menunjukkan bahwa perlakuan tidak berpengaruh nyata $(\mathrm{P}>0,05)$ terhadap total konsumsi ransum, biaya ransum, dan total biaya, akan tetapi memberikan pengaruh nyata $(\mathrm{P} \leq 0,05)$ terhadap total massa telur, pendapatan penjualan telur, keuntungan, dan $R / C$ ratio. Penambahan tepung daun jati pada level $1,2 \%$ dan $1,6 \%$ dapat meningkatkan $(\mathrm{P} \leq 0,05)$ total massa telur, pendapatan penjualan telur, keuntungan, dan $R / C$ ratio jika dibandingkan dengan perlakuan control, tetapi perlakuan tersebut tidak berpengaruh nyata $(\mathrm{P}>0,05)$ jika dibandingkan dengan perlakuan AV. Kesimpulan peneltiian bahwa tepung daun jati dapat digunakan sebagai aditif pakan untuk meningkatkan profitabilitas ayam petelur dan penggunaan tepung daun jati pada level 1,2\% efektif untuk menggantikan antibiotik sintetis.
\end{abstract}

Kata kunci: Aditif pakan, Antibiotik, Fitobiotik, $R / C$ ratio, Tectona grandis $\mathrm{L}$.

\section{ABSTRACT}

This study was conducted to evaluate the effect of dietary teak leaves powder as an alternative substitute for synthetic antibiotic on profitability of laying hens. The materials used in this study were 240 30-week-old Isa Brown laying hens. The birds were randomly divided into 6 treatments with 4 replications (each replication consisted of 10 birds). The treatments used were control treatment: without any feed additive, AV: 0.05\% antibiotic virginiamycin, and dietary teak leaves powder supplementation at the level of $0.4 \%, 0.8 \%, 1.2 \%$, and $1.6 \%$. The results showed that the treatments did not significantly $(P>0.05)$ affect total ration intake, ration cost, and total cost, but gave significant effects $(P \leq 0.05)$ on total egg mass, income from selling egg, profit, and R/C ratio. The inclusion of teak leaves powder at the level of $1.2 \%$ and $1.6 \%$ could increase $(P \leq 0.05)$ total egg mass, revenue from selling egg, profit, and $R / C$ ratio as compared to control treatment. However, they did not significantly differ $(P>0.05)$ as compared to AV treatment. Consclusion of this research that the teak leaves powder could be used as a feed additive to improve profitability of laying hens and the use of teak leaves powder at the level of $1.2 \%$ effectives to substitute synthetic antibiotic.

Keywords: Antibiotic, Feed additive, Phytobiotic, $R / C$ ratio, Tectona grandis $\mathrm{L}$. 


\section{PENDAHULUAN}

Ayam petelur memegang peranan penting untuk menyediakan pangan berkualitas untuk masyarakat. Berdasarkan Direktorat Jenderal Peternakan dan Kesehatan Hewan (2018), Populasi ayam petelur di Indonesia pada tahun 2014 sejumlah 147 juta ekor, jumlah ini meningkat menjadi 182 juta ekor pada tahun 2018. Di sisi produktivitas, produksi telur pada tahun 2014 adalah 1,24 juta ton, yang kemudian meningkat menjadi 1,64 juta ton pada tahun 2018 . Menurut Pusat Data dan Sistem Informasi Pertanian (2018), kebutuhan konsumsi telur nasional akan terus meningkat pada tahun-tahun mendatang dengan angka peningkatan sejumlah $2,45 \%$ per tahun. Kondisi ini menuntut adanya strategi untuk meningkatkan produktivitas ayam petelur.

Ransum memegang peranan penting untuk menentukan produktivitas dan profitabilitas ayam petelur. Selama beberapa dekade terakhir, antibiotik sintetis digunakan secara luas sebagai aditif pakan yang berperan untuk meningkatkan penampilan produksi ayam petelur (Khan et al., 2011; Bozkurt et al., 2012). Akan tetapi, penggunaan antibiotik tersebut kini mulai ditinggalkan karena dapat menghasilkan residu pada produk dan menyebabkan berkembangnya bakteri resisten yang berbahaya bagi kesehatan manusia (Nhung et al., 2016; Xiong et al., 2018; Yang et al., 2019). Salah satu upaya yang dapat dilakukan untuk menggantikan antibiotik adalah dengan menggunakan fitobiotik.
Daun jati (Tectona grandis L.) adalah satu kandidat potensial yang dapat digunakan sebagai aditif pakan pengganti antibiotik. Daun jati memiliki komponen bioaktif berupa flavonoid (Arief et al., 2014) yang dapat berfungsi sebagai agen antibakteri (Vyas et al., 2018), selain itu daun jati juga memiliki aktivitas antioksidan (Devadiga et al., 2015) yang diharapkan dapat mendukung produktivitas, sehingga dapat meningkatkan profitabilitas usaha ternak unggas. Penggunaan tepung daun jati (TDJ) sebagai aditif pakan ayam petelur sangat jarang dilakukan, oleh karena itu penelitian ini dilakukan untuk mengevaluasi pengaruh penggunaan TDJ terhadap profitabilitas ayam petelur.

\section{MATERI DAN METODE}

Proses pembuatan TDJ diawali dengan proses pelayuan selama $24 \mathrm{jam}$, setelah itu daun jati dikeringkan dengan oven pada suhu $45^{\circ} \mathrm{C}$ selama 36 jam kemudian digiling hingga menjadi tepung dengan ukuran 60 mesh. Penelitian dilakukan menggunakan 240 ekor ayam petelur strain Isa Brown berumur 30 minggu. Rata-rata egg mass ayam petelur sebelum penelitian adalah $54,02 \pm 4,31 \mathrm{~g}$. Tiap ayam ditempatkan pada kandang baterai berukuran 20 x 35 × $40 \mathrm{~cm}$. Ransum diberikan 125 g/ekor/hari, sedangkan pemberian air minum dilakukan secara ad libitum. Komposisi dan kandungan nutrien ransum basal yang digunakan pada penelitian ini dapat dilihat pada Tabel 1. Ransum disusun untuk memenuhi kebutuhan nutrien ayam petelur sesuai Hy-Line International (2014).

Tabel 1. Komposisi dan kandungan nutrien ransum basal (Composition and nutrient content of basal ration)

\begin{tabular}{lc}
\hline Bahan pakan (Feed ingredient) & Komposisi (Composition) (\%) \\
\hline Jagung (corn) & 54,32 \\
Bungkil kedelai (Soybean meal) & 18,16 \\
Bekatul (Bran) & 8,69 \\
Tepung tulang daging (Meat bone meal) & 8,00 \\
Menir batu (Rock groats) & 5,76 \\
Tepung batu (Stone flour) & 2,88 \\
Minyak kelapa sawit (Palm oil) & 1,50 \\
DL-Methionine & 0,17 \\
L-Lysine HCl & 0,14 \\
Garam (Salt) & 0,11 \\
Natrium bikarbonat (Sodium bicarbonate) & 0,09 \\
Anti jamur (Anti-mildew) & 0,08 \\
Vitamin-mineral premix & 0,05 \\
\hline Kandungan nutrient (Nutrient content) & \\
\hline Energi termetabolis (Metabolic energy) (Kkal/Kg) & 2.830 \\
Protein kasar (Crude protein) (\%) & 17,88 \\
Lemak kasar (Crude fat) (\%) & 5,64 \\
Kalsium (Calsium) (\%) & 4,08 \\
Fosfor total (Total Phosphate) (\%) & 0,78 \\
\hline
\end{tabular}


Metode penelitian yang digunakan adalah percobaan menggunakan rancangan acak lengkap dengan 6 perlakuan dan 4 ulangan (masingmasing menggunakan 10 ekor ayam petelur). Perlakuan yang digunakan pada penelitian ini terdiri dari perlakuan kontrol: tanpa aditif pakan, AV: $\quad 0,05 \%$ antibiotik virginiamycin, dan penambahan TDJ pada level $0,4 \%, 0,8 \%, 1,2 \%$, dan $1,6 \%$. Perlakuan diberikan selama 9 minggu (umur 30-38 minggu).

Variabel yang diamati pada penelitian ini adalah total massa telur, total konsumsi ransum, pendapatan penjualan telur, biaya ransum, total biaya, keuntungan, dan $R / C$ ratio. Data massa telur dan konsumsi ransum diukur setiap hari selama penelitian. Data variabel harga/biaya selama penelitian ditampilkan pada Tabel 2 . Pendapatan penjualan telur dihitung dengan cara total massa telur $\mathrm{x}$ harga telur. Biaya ransum dihitung dengan cara total konsumsi ransum $\mathrm{x}$ harga ransum. Total biaya dihitung dengan cara biaya ransum + biaya bibit, kandang, dan tenaga kerja. Keuntungan dihitung dengan cara pendapatan penjualan telur - total biaya. $R / C$ ratio dihitung dengan cara pendapatan penjualan telur / total biaya. Data dianalisis dengan analysis of variance yang dilanjutkan dengan uji Duncan Multiple Range Test.

\section{HASIL DAN PEMBAHASAN}

Tabel 3 menunjukkan pengaruh penambahan TDJ dalam ransum terhadap profitabilitas ayam petelur. Perlakuan tidak berpengaruh nyata $(\mathrm{P}>0,05)$ terhadap total konsumsi ransum, biaya ransum, dan total biaya, tetapi memberikan pengaruh nyata $(\mathrm{P} \leq 0,05)$ terhadap total massa telur, pendapatan penjualan telur, keuntungan, dan $R / C$ ratio.

Tabel 2. Data variabel harga/biaya selama penelitian (Data of cost variables during experimental period)

\begin{tabular}{|c|c|c|c|c|c|c|}
\hline \multirow{2}{*}{ Variabel } & \multirow{2}{*}{ Kontrol } & \multirow{2}{*}{$\mathbf{A V}$} & \multicolumn{4}{|c|}{ TDJ } \\
\hline & & & $0,4 \%$ & $\mathbf{0 , 8 \%}$ & $1,2 \%$ & $1,6 \%$ \\
\hline Harga ransum $(\mathrm{Rp} / \mathrm{kg})$ & 4.821 & 4.969 & 4.830 & 4.838 & 4.847 & 4.856 \\
\hline $\begin{array}{l}\text { Biaya bibit, kandang, dan } \\
\text { tenaga kerja (Rp/ekor) }\end{array}$ & 5.304 & 5.304 & 5.304 & 5.304 & 5.304 & 5.304 \\
\hline Harga telur $(\mathrm{Rp} / \mathrm{kg})$ & 18.500 & 18.500 & 18.500 & 18.500 & 18.500 & 18.500 \\
\hline
\end{tabular}

Keterangan: AV = Antibiotik Virginiamycin, TDJ = Tepung Daun Jati

Tabel 3. Pengaruh penambahan tepung daun jati dalam ransum terhadap profitabilitas ayam petelur umur 30-38 minggu (The effect of dietary teak leaves powder supplementation on profitability of laying hens aged at 30-38 weeks)

\begin{tabular}{|c|c|c|c|c|c|c|}
\hline \multirow{2}{*}{ Variabel } & \multirow{2}{*}{ Kontrol } & \multirow{2}{*}{$\mathbf{A V}$} & \multicolumn{4}{|c|}{ TDJ } \\
\hline & & & $0,4 \%$ & $\mathbf{0 , 8 \%}$ & $1,2 \%$ & $1,6 \%$ \\
\hline $\begin{array}{l}\text { Total } \\
\text { konsumsi } \\
\text { ransum } \\
\text { (kg/ekor) }\end{array}$ & $6,67 \pm 0,18$ & $6,73 \pm 0,07$ & $6,67 \pm 0,10$ & $6,72 \pm 0,25$ & $6,74 \pm 0,08$ & $6,73 \pm 0,25$ \\
\hline $\begin{array}{l}\text { Total massa } \\
\text { telur } \\
\text { (kg/ekor) }\end{array}$ & $2,63 \pm 0,16^{\mathrm{a}}$ & $3,42 \pm 0,22^{c}$ & $2,67 \pm 0,14^{\mathrm{a}}$ & $2,91 \pm 0,12^{\mathrm{ab}}$ & $3,33 \pm 0,20^{\mathrm{c}}$ & $3,18 \pm 0,22^{b c}$ \\
\hline $\begin{array}{l}\text { Biaya } \\
\text { ransum } \\
\text { (Rp/ekor) }\end{array}$ & $32.136 \pm 869$ & $33.439 \pm 326$ & $32.185 \pm 493$ & $32.525 \pm 1.205$ & $32.652 \pm 375$ & $32.696 \pm 1.208$ \\
\hline $\begin{array}{l}\text { Total biaya } \\
\text { (Rp/ekor) }\end{array}$ & $37.440 \pm 869$ & $38.743 \pm 326$ & $37.489 \pm 493$ & $37.829 \pm 1.205$ & $37.956 \pm 375$ & $38.000 \pm 1.208$ \\
\hline $\begin{array}{l}\text { Penjualan } \\
\text { telur } \\
\text { (Rp/ekor) }\end{array}$ & $48.649 \pm 2.840^{\mathrm{a}}$ & $63.186 \pm 4.123^{b}$ & $49.431 \pm 2.548^{a}$ & $53.856 \pm 2.190^{\mathrm{a}}$ & $61.541 \pm 3.702^{b}$ & $58.837 \pm 4.126^{b}$ \\
\hline $\begin{array}{l}\text { Keuntungan } \\
\text { (Rp/ekor) }\end{array}$ & $11.209 \pm 2.099^{a}$ & $24.444 \pm 4.428^{c}$ & $11.942 \pm 2.637^{\mathrm{a}}$ & $16.028 \pm 1.641^{\mathrm{ab}}$ & $23.585 \pm 4.053^{\mathrm{c}}$ & $20.836 \pm 5.260^{b c}$ \\
\hline $\mathrm{R} / \mathrm{C}$ ratio & $1,30 \pm 0,05^{\mathrm{a}}$ & $1,64 \pm 0,12^{\mathrm{c}}$ & $1,32 \pm 0,07^{\mathrm{a}}$ & $1,43 \pm 0,04^{\mathrm{ab}}$ & $1,62 \pm 0,11^{\mathrm{c}}$ & $1,55 \pm 0,16^{\mathrm{bc}}$ \\
\hline
\end{tabular}

Keterangan: AV = Antibiotik Virginiamycin, TDJ = Tepung Daun Jati. Superskrip yang berbeda pada baris yang sama menunjukkan perbedaan yang nyata $(\mathrm{P} \leq 0,05)$ 
Penambahan teoung daun jati (TDJ) pada level $1,2 \%$ dan $1,6 \%$ dapat meningkatkan $(\mathrm{P} \leq 0,05)$ total massa telur, pendapatan penjualan telur, keuntungan, dan $R / C$ ratio jika dibandingkan dengan perlakuan control, tetapi perlakuan tersebut tidak berbeda nyata $(\mathrm{P}>0,05)$ jika dibandingkan dengan perlakuan AV.

Tidak adanya pengaruh dari penambahan TDJ dalam ransum terhadap total konsumsi ransum diduga karena perlakuan tidak memberikan banyak perubahan terhadap kandungan nutrien pada ransum. Hal ini karena penambahan TDJ dilakukan pada level yang rendah $(0,4-1,6 \%)$, selain itu penambahan TDJ diduga juga tidak mempengaruhi palatabilitas ransum sehingga total konsumsi ransum tidak berbeda nyata. Hasil ini kemudian juga diikuti dengan tidak adanya pengaruh nyata dari perlakuan terhadap biaya ransum dan total biaya, yang mana hal ini juga dipengaruhi oleh harga ransum yang tidak berubah secara drastis.

Hasil penelitian menunjukkan bahwa penggunaan TDJ (terutama pada level 1,2\%) dapat meningkatkan total massa telur ayam petelur dengan efektivitas yang setara dengan penggunaan antibiotik virginiamycin. Hasil ini diduga berkaitan erat dengan kandungan fitokimia yang dimiliki daun jati. TDJ dilaporkan memiliki kandungan flavonoid sebesar 0,17\% (Edi et al., 2018). Kandungan flavonoid tersebut mampu bertindak sebagai agen antibakteri dalam saluran pencernaan. Liu et al. (2014) melaporkan bahwa penggunaan flavonoid dapat menurunkan bakteri Coliforms pada seka ayam petelur. Penurunan bakteri tersebut akan berdampak pada peningkatan ketersediaan nutrien yang diperlukan untuk proses produksi. Ren et al. (2018) juga melaporkan bahwa penggunaan flavonoid dari daun Ginkgo biloba juga dapat meningkatkan kecernaan nutrien.

Efek positif penggunaan TDJ terhadap total massa telur diduga juga berkaitan dengan aktivitas antioksidan yang dimilikinya. TDJ memiliki aktivitas antioksidan sebesar 56,22\% (Edi et al., 2018). Senyawa antioksidan dari tanaman herbal dilaporkan dapat meningkatkan tinggi vili (Giannenas et al., 2011), yang mana hal ini akan mendukung proses pencernaan dan penyerapan nutrien, sehingga produktivitas ternak unggas akan mengalami peningkatan. Sebagaimana juga dilaporkan oleh Lin et al. (2017) bahwa penggunaan daun murbei sebagai aditif pakan sumber antioksidan dapat meningkatkan massa telur ayam petelur.

Peningkatan total massa telur sebagai akibat dari penggunaan TDJ diikuti dengan meningkatnya pendapatan penjualan telur, yang pada akhirnya juga berakibat terhadap peningkatan keuntungan dan nilai $R / C$ ratio ayam petelur. Pada perlakuan TDJ 1,2\%, pendapatan penjualan telur meningkat hingga Rp. 12.892/ekor, sedangkan keuntungan meningkat Rp. $12.376 /$ ekor, dan $R / C$ ratio meningkat 0,32 poin dibandingkan dengan kontrol. Hingga saat ini, evaluasi profitabilitas dari penggunaan fitobiotik pada ayam petelur masih sangat jarang dilakukan. Hasil penelitian ini memberikan indikasi kuat bahwa TDJ memiliki potensi besar untuk meningkatkan profitabilitas usaha ayam petelur.

\section{SIMPULAN}

Tepung daun jati dapat digunakan sebagai aditif pakan untuk meningkatkan profitabilitas ayam petelur dan penggunaan tepung daun jati pada level $1,2 \%$ dapat efektif untuk menggantikan antibiotik sintetis.

\section{DAFTAR PUSTAKA}

Arief, I. I., T. Suryati, D. N. Afiyah, and D. P. Wardhani. 2014. Physicochemical and organoleptic of beef sausages with teak leaf extract (Tectona grandis) addition as preservative and natural dye. Int. Food Res. J. 21: 2033-2042.

Bozkurt, M., K. Küçükyilmaz, M. Pamukçu, M. Çabuk, A. Alçiçek, and A. U. Çatli. 2012. Long-term effects of dietary supplementation with an essential oil mixture on the growth and laying performance of two layer strains. Ital. J. Anim. Sci. 11(1): 23-28 p.e5.

Devadiga, A., K. V. Shetty, and M. B. Saidutta. 2015. Timber industry waste-teak (Tectona grandis Linn.) leaf extract mediated synthesis of antibacterial silver nanoparticles. Int. Nano Lett. 5: 205-214.

Direktorat Jenderal Peternakan dan Kesehatan Hewan. 2018. Statistik Peternakan dan Kesehatan Hewan 2018. Kementerian Pertanian. Jakarta.

Edi, D.N., M.H. Natsir, I.H. Djunaidi. 2018. The effect of dietary teak leaf extract (Tectona grandis Linn. $f$ ) on egg quality of laying hens. Sch. J. Agric. Vet. Sci. 5(9): 490-497.

Giannenas, I., E. Bonos, I. Skoufos, A. Tzora, I. Stylianaki, D. Lazari, A. Tsinas, E. Christaki, and P. Florou-Paneri. 2018. Effect of herbal feed additives on performance parameters, intestinal microbiota, intestinal morphology and meat lipid oxidation of broiler chickens. Br. Poult. Sci., 59(5): 545-553. 
Hy-Line International. 2014. Panduan Manajemen Ayam Petelur Komersial HyLine Brown. Hy-Line International, Des Moines, Iowa.

Khan, S. H., M. Atif, N. Mukhtar, A. Rehman, and G. Fareed. 2011. Effects of supplementation of multi-enzyme and multi-species probiotic on production performance, egg quality, cholesterol level and immune system in laying hens. J. Appl. Anim. Res. 39: 386-398.

Lin, W. C., M. T. Lee, S. C. Chang, Y. L. Chang, C. H. Shih, B. Yu, and T. T. Lee. 2017. Effects of mulberry leaves on production performance and the potential modulation of antioxidative status in laying hens. Poult. Sci., 96(5): 1191-1203.

Liu, H. N., Y. Liu, L. L. Hu, Y. L. Suo, L. Zhang, F. Jin, X. A. Feng, N. Teng, and Y. Li. 2014. Effects of dietary supplementation of quercetin on performance, egg quality, cecal microflora populations, and antioxidant status in laying hens. Poult. Sci., 93(2): 347-353.

Nhung, N. T., N. V. Cuong, G. Thwaites, J. Carrique-Mas. 2016. Antimicrobial usage and antimicrobial resistance in animal production in Southeast Asia: a review. Antibiotics, 5(4): 37.

Pusat Data dan Sistem Informasi Pertanian. 2018. Outlook Telur 2018. Kementerian Pertanian. Jakarta.

Ren, X. J., Z. B. Yang, X. Ding, and C. W. Yang. 2018. Effects of Ginkgo biloba leaves (Ginkgo biloba) and Ginkgo biloba extract on nutrient and energy utilization of broilers. Poult. Sci. 97(4): 1342-1351.

Vyas, P., D. K. Yadav, and P. Khandelwal. 2019. Tectona grandis (teak)-A review on its phytochemical and therapeutic potential. Nat. Prod. Res., 33(16): 2338-2354.

Xiong, W., Y. Sun, and Z. Zeng. 2018. Antimicrobial use and antimicrobial resistance in food animals. Environ. Sci. Pollut. Res. Int., 25(19): 18377-18384.

Yang, Y., A. J. Ashworth, K. Cook, C. Willett, A. Upadhyay, P. Owens, S. C. Ricke, J. M. DeBruyn, and P. A. Moore. 2019. Review of antibiotic resistance, ecology, dissemination, and mitigation in US broiler poultry systems. Front. Microbiol., 10: 1-10. 